\title{
Se póde ser inventariante o herdeiro que promove a annullação do testamento do inventariado
}

\author{
Noé Azevedo
}

\section{PARECER}

A consulta versa sobre a seguinte questão:

Póde a herdeira que, nessa qualidade e na de inventariante, intentou acção de nullidade de testamento, ser mantida no cargo de inventariante dos bens da testadora, que distribuiu grande parte da herança em legados?

A funcção principal do inventariante é a de promover a partilha da herança.

Essa partilha tem de ser feita de accôrdo com á lei e com o testamento. $\mathrm{O}$ inventario deve ser iniciado dentro de um mez a contar da abertura da successão, ultimando-se a partilha dentro de três mezes. E' o que dispõe o art. 1.770 do Codigo Civil. E essa disposição é de ordem pública. O Estado tem interesse de natureza fiscal, que reclama o rapido andamento dos inventarios, e, além disso, ha um grande interesse público na declaração da parte de cada um dos herdeiros e legatarios na successão.

A demora na conclusão dos inventarios e partilhas deixa em suspenso as relações juridicas ligadas á successão. Pela mesma razão de ordem pública que determinou o legislador a abolir o instituto da herança jacente, foi estabelecido o 
preceito do art. 1.770 do Codigo Civil, para que as protelações indefinidas dos inventarios não importassem na continuação do instituto abolido.

Assim, quando alguem assume compromisso de inventariante, obriga-se a não suscitar dúvidas e levantar questões que impeçam a conclusão do inventario no prazo legal.

"Portanto, escreve Carlos Maximiliano, se o inventariante suscita dúvidas propositadas ou dá origem a demandas, retarda a partilha além do prazo legal e das prorogações concedidas; emfim, quando apesar de notificado não responde, não se explica, não dá andamento ou não conclue o trabalho, é removido, podendo, até, ser o espolio sequestrado e entregue a outro inventariante nomeado pelo juiz" ("Direito das Successões", ed. de 1937, vol II, pag. 597, n. ${ }^{\circ}$ 1.441, cf. Itabaiana DE Oliveira, "Successões", ed. de 1929, pag. 502, $\S 752$; Pinto DE Toledo, "Processo Orphanologico", ed. de 1922, pag. 62, § 182; Ramalho, "Instituições Orphanologicas", ed. de 1874, pag. 214, § 92; Borges Carneiro, "Direito Civil", vol. II, pag. 132; Teixeira de Freitas, "Doutrina das Acções", ed. Garnier, pag. 89, nota 256).

Commentando o art. 1.770 do Codigo Civil, escreve Clovis :

"Tem a lei em tal conta a necessidade de se pôr termo á indivisão da herança, que permitte iniciar e continuar nas férias o processo de inventario, e commina a pena de remoção ao inventariante que, por culpa sua, não termina as partilhas dentro da prorogação do prazo que lhe é concedida pelo juiz, privando-o, além disso, do premio, se fôr testamenteiro"

E' para evitar a protelação que se remettem para as vias ordinarias todas as questões de alta indagação, segundo a lição do mesmo Clovis Bevilaqua:

"A brevidade exigida pela lei para terminação do inventario e a natureza administrativa do pro- 
cesso respectivo excluem certas fórmas e termos processuaes, assim como as questões de alta indagação, que se remettem para as vias ordinarias".

Condensando essa doutrina, temos o preceito do art. 873, n. ${ }^{\circ}$ II, do Codigo de Processo do Estado:

"Além dos casos expressos em lei, o inventariante será destituido se não dér ao inventario o devido andamento, ou suscitar dúvidas protelatorias".

Como poderá o juiz deferir compromisso de inventariante a um herdeiro que tenha proposto acção de annullação do testamento, de accôrdo com o qual deve promover a partilha no prazo determinado pela lei?

Semelhante acção, envolvendo questão de alta indagação, será necessariamente demorada, sendo impossivel obter-se decisão definitiva a tempo de realizar-se a partilha no prazo legal.

Desse modo, tendo manifesto interesse em protelar a partilha, o herdeiro legitimo, ao assumir o compromisso de inventariante e assumir a obrigação de promover a partilha no prazo legal, estaria mentindo ao juiz, ou perjurando, de accôrdo com a technica dos velhos orphanologistas, pois, segundo a nossa antiga legislação, seria applicavel, nesse caso, a pena de perjuro.

"E acceitando o juramento, fica o inventariante sujeito ás penas de perjuro, de sonegados e ás mais das leis, pelas omissões ou faltas em que fôr achado" (Ramalho, ob. cit. pag. 211, com fund. na Ord. Liv. I, tit. 88, § 9; em Gama, "Decisões", 122, 148; e em Vallasco, "Partit." cap. 8. ${ }^{\circ}$, n. 36 e sgs.).

E como poderá o juiz manter no cargo de inventariante a quem, faltando aos deveres desse cargo e invocando ex- 
pressamente essa qualidade de inventariante, intentou acção de annullação do testamento, cujas determinações se obrigou a respeitar, assumindo o compromisso de promover a partilha no prazo legal, partilha que tem de necessariamente ser regulada por esse testamento?

Dizemos que o inventariante faltou aos deveres do cargo intentando a acção de annullação do testamento, porque, segundo a disposição do art. 1.760 do nosso Codigo Civil, é dever do inventariante defender a validade do testamento.

Dispõe esse texto que

"Compete ao testamenteiro, com ou sem o concurso do inventariante e dos herdeiros instituidos, propugnar a validade do testamento"

O art. 1.719 do Projecto Clovis, regulando as attribuições do testamenteiro, dispunha:

"Cumpre-lhe sustentar a validade do testamento, exclusivamente, se fôr inventariante, e, conjuntamente com o inventariante, se outrem exercer esse cargo".

A commissão revisora preferiu, entretanto, dar ao testamenteiro competencia para agir sozinho, substituindo o art. 1.919 do Projecto Clovis pelo art. 2.130 do Revisto:

"Compete ao testamenteiro defender a validade do testamento, por si ou com o inventariante e demais herdeiros instituidos"

"Prevaleceu esta amplitude, mercê do art. 1.760 do Codigo, fórmula retocada, quanto á linguagem apenas, do art. 2.130 da commissão revisora" (Carlos Maximiliano, ob. cit. $\S 1.384)$. 
Do facto do legislador permittir que o testamenteiro defenda sozinho a validade do testamento, não resulta a conclusão de que tenha tirado ao inventariante essa attribuição, dispensando-o desse dever. O que aconteceu foi que o Codigo Civil discriminou todas as attribuições do testamenteiro, considerando isso como materia de Direito Civil, tendo, entretanto, deixado de enumerar as attribuições, direitos e deveres do inventariante, naturalmente porque o legislador da República entendeu que isso constituia materia de Processo Civil.

Assim, apenas incidentemente, e no que é essencial, faz referencias á figura do inventariante ou cabeça de casal e aos seus deveres.

Mas, dizendo no art. 1.760 que o testamenteiro defenderá sozinho, ou com o concurso de inventariante, a validade do testamento, mostra o legislador que é dever do inventariante defender o testamento.

Quis ampliar as funcções do testamenteiro, permittindo que, mesmo sozinho, elle defendesse o testamento. Mas, com isso, não dispôs que o inventariante seja dispensado de defender a validade do mesmo.

Dizendo que o testamenteiro, com ou sem o concurso do inventariante, deve propugnar a validade do testamento, o Codigo dá ao inventariante competencia para defender o testamento. E' indiscutivel, portanto, o seu direito de propugnar a validade do mesmo. Mas, tratar-se-á apenas de um direito ou tambem de um dever?

Entendemos que é um dever porque, ao prestar declarações, o inventariante é obrigado a dizer se o inventariado deixou ou não testamento (Cod. do Processo, art. 855, n. ${ }^{\circ} \mathrm{I}$ ). $\mathrm{E}$, feitas as primeiras declarações, deve ser junto aos autos do inventario o testamento. Quando este já é junto, o juiz ordenou o seu cumprimento, no processo de execução do mesmo. E' junto ao processo do inventario para que as suas disposições sejam observadas pelo inventariante.

De accôrdo com essas disposições e com a lei, tem o inventariante de promover a partilha, no restricto prazo legal, 
não podendo suscitar dúvidas que retardem a conclusão ou finalização do processo.

Se o dever do inventariante é fazer o inventario e promover a partilha, de accôrdo com a lei e com o testamento, tem elle necessariamente de defender a validade deste.

Se ha um despacho do juiz mandando cumprir o testamento, se, por força de disposição expressa de lei, este é junto aos autos do inventario logo após as primeiras declarações, conclue-se que o inventariante tem de, forçosamente, cumprir as disposições testamentarias.

A obrigação que elle assume, de promover a partilha na successão regulada pelo testamento, envolve a de cumprir esse testamento. Tendo de partilhar os bens de accôrdo com o mesmo, tem necessariamente o dever de pugnar pela validade das suas disposições.

Pensamos, por isso, que commette uma falta de exacção no cumprimento dos seus deveres o inventariante que deixa de propugnar a validade do testamento.

Mas, no caso da consulta, a falta é muito mais grave. Não houve apenas inércia da parte da herdeira que assumiu o cargo de inventariante. Ella não se limitou a descurar da defesa do testamento. Tomou uma attitude abertamente contrária á lei. Iniciou, na qualidade de inventariante, uma acção para annullação do testamento.

Se pretendia annullal-o, como poderia assumir o compromisso de promover a partilha no restricto prazo da lei, de accôrdo com o testamento que o juiz mandou cumprir?

Um compromisso deferido em taes condições não passará de uma burla, tolerada pelo magistrado.

Por outro lado, não ha lei que dê ao inventariante a attribuição de promover a acção de nullidade do testamento. Seria mesmo absurda qualquer disposição de lei nesse sentido. Embora a herança não tenha personalidade juridica, é contra ella que se propõe a acção de annullação do testamento. 
Ensinam os escriptores da materia que o inventariante é o administrador da herança.

Para CoElHo dA RochA "o inventariante é um administrador legal da massa commum, e, nesta qualidade, e pelo proprio interesse, deve nella ter cuidados positivos; e por isso a lei lhe confere a posse e lhe permitte dispôr dos frutos, até negociar com elles. E' um direito equiparado ao de um procurador ou mandatario geral" ("Direitc Civil Português", vol. II, nota U - apud Astolpho Rezende, "Manual do Cod. Civil", vol. XX, pag. 175).

Para o Barão de Ramalho, "o cabeça de casal durante o inventario não exerce sobre os bens da herança senão o direito de administração" ("Instituições orphanologicas" nota 621).

Escreve Carlos Maximiliano que os nossos escriptores "não o consideram mandatario nem depositario; porém méro administrador de bens alheios» (ob. cit. $\S 1.438$ ).

Como administrador da herança que se regula pelo testamento, não poderá propôr a acção de nullidade deste. Somente poderá usar dos poderes geraes de administração. Para praticar outros quaesquer actos que exorbitem da administração ordinaria, são indispensaveis poderes especiaes e expressos (Cod. Civ. art. 1.295, § 1..$^{\circ}$ ).

Trazendo a acção de nullidade do testamento, relativo á herança ainda não partilhada, a pretensão de uma verdadeira petição de herança, tem de ser dirigida contra o possuidor da mesma. Sendo possuidor o inventariante, na qualidade de administrador, tem elle de ser citado como réu em dita acção.

Do contrário, depois de julgada procedente a acção de nullidade do testamento, ainda seria necessaria uma acção de petição de herança.

Por isso, entendemos que, tratando-se de herança ainda não partilhada, não é apenas util a citação do inventariante, segundo o conselho de Clovis, mas necessaria. (Commentario ao art. 1.760 do Cod. Civ.). 
Se o inventariante tem de ser citado como réu, é evidentemente absurdo que possa funccionar como autor na acção de nullidade do testamento.

Poderiam invocar a doutrina de Hermenegildo de Barros sobre o art. 1.580 do Codigo Civil para sustentar que, sendo a inventariante herdeira legitima, poderá como qualquer herdeiro mover a acção de nullidade do testamento.

$\mathrm{Na}$ qualidade de herdeira, sim; mas na de inventariante, nunca.

Entendemos ser muito logica a doutrina de HermeneGILDO DE BARros, sustentando que, se o simples herdeiro póde, com fundamento no art. 1.580, $\S$ un., reclamar a universalidade da herança ao terceiro que indevidamente a possúa, tambem o inventariante que seja herdeiro póde, naquella qualidade, mover as acções que forem necessarias contra terceiros, objectivando bens da herança.

Mas o facto de poder demandar contra terceiro, por força desse paragrapho, não induz a conclusão de que tambem possa demandar contra a propria herança, por elle mesmo representada, e contra os herdeiros instituidos, que não são terceiros.

Dispõe o art. 1.580, $\S$ unico:

"Qualquer dos co-herdeiros póde reclamar a universalidade da herança ao terceiro que indevidamente a possúa, não podendo este oppor-lhe, em excepção, o caracter parcial do seu direito nos bens da successão"

Com base nesse artigo sustenta-se, seguindo a doutrina de Hermenegildo de Barros, que cessaram as restriç̧ões ao direito de acção do inventariante contra terceiros, visando a integração do acérvo hereditario. Resolve-se a velha disputa dos nossos orphanologistas, sobre poder ou não o inventariante propôr demandas em nome do espolio, visando reivindicações, cobrança de dividas, etc., em face da legislação 
antiga, que limitava a sua actuação ás questões possessorias. (v. Astolpho Rezende, ob. cit. pag. 188).

Mas, desse texto não se póde tirar a conclusão de que sendo o inventariante herdeiro legitimo possa tambem, na qualidade de inventariante, intentar acção de nullidade do testamento, contra os herdeiros instituidos ou legatarios. Esses herdeiros testamentarios ou legatarios, que integram a successão, com os herdeiros legitimos, não pódem ser considerados como terceiros, relativamente a essa mesma successão.

Constituirá, portanto, um absurdo a pretensão de tirar do art. $1.580, \S$ un. poderes para o inventariante intentar acção de nullidade do testamento contra os herdeiros instituidos e legatarios.

Se o simples facto de suscitar dúvidas protelatorias determina a destituição do inventariante, segundo o disposto no art. 1.873, n. ${ }^{\circ}$ II do Cod. do Processo, como se ha de manter no cargo a herdeira legitima que, invocando expressamente a qualidade de inventariante, move uma acção de nullidade de testamento que era obrigada a cumprir em obediencia aos deveres do cargo e a despacho do mesmo juiz?

Emquanto vigorar o testamento, serão partes interessadas no espolio os herdeiros instituidos e os legatarios. Se a situação juridica do inventariante, segundo CoElHo da Rocha, é a de administrador da massa commum, em que são interessados tanto os herdeiros legitimos como os testamentarios, se elle tem a representação geral de todos, se é equiparado, segundo o mesmo escriptor, a um procurador ou mandatario geral, - como poderá agir contra aquelles cujo interesse representa?

Mesmo que não se considerem como partes, technicamente falando, os legatarios, em se tratando de legados de cousa certa, elles serão incontestavelmente pessôas com interesses no espolio.

Esses interesses, até á partilha, são administrados pelo inventariante. Este é, portanto, o representante geral dos 
legatarios, quanto aos interesses que os mesmos têm no espolio.

Movendo a acção de nullidade do testamento contra os herdeiros instituidos e legatarios, o inventariante age contra os seus proprios representados.

Fica, pois, demonstrado que não ha texto legal que sirva de fundamento para a attribuição de annullar as disposições de ultima vontade da inventariada, que o inventariante se arrogou.

Houve uma exorbitancia da sua parte. E além de ser exorbitante, o seu procedimento contraria a natureza juridica da sua funcção, assim como a propria finalidade do cargo.

São essas as considerações com que justificamos o nosso parecer, no sentido de ter se incompatibilizado para o exercicio do cargo de inventariante a herdeira que, na dupla qualidade de herdeira e de inventariante, intentou acção de nullidade do testamento.

Queremos, entretanto, finalizar este trabalho com a ponderada lição de um grande mestre, na mais recente das obras sobre o Direito das Successões.

No $\S 1.439$, vol. II, pag. 595, do seu "Direito das Successões", escreve Carlos Maximiliano:

"Affirma-se ter o Codigo Civil, por meio do $\S$ un. do art. 1.580 , resolvido affirmativamente a seguinte questão vetusta: póde o inventariante accionar e ser accionado "in solidum"?

"Em verdade, assim acontece, dahi, porém, se não conclúa, em favor do cabeça de casal, a faculdade ampla de envolver em demandas a successão, e, para os litigantes por causa do espolio, a dispensa de citar os herdeiros e outros interessados. Póde o inventariante intervir sozinho sem serem chamados a juizo os successores universaes ou singulares, nas causas em que lhe cabe agir como 
autor ou réu, isto é, na defesa da validade do testamento, na cobrança de dividas activas, no despejo de prédios, nas acções possessorias e nas reivindicatorias, cabendo-lhe tambem o direito e o dever de tomar medidas conservatorias, como sejam, as interrupções da prescripção, arrestos, sequestros. Uma funcção de objectivos determinados e restrictos e destinada a durar só quatro mezes é incompativel com iniciativas de grande vulto e o empenho em grandes litigios"

$\mathrm{E}$ em que maior litigio poderia se envolver o espolio do que numa acção de annullação de testamento? Sendo o testamento o estatuto fundamental da successão testamentaria, o inventariante que o impugna impossibilita a conclusão do inventario e a realização da sua finalidade, que é a partilha dos bens de accôrdo com a vontade do testador.

Se as simples dúvidas protelatorias determinam o afastamento do inventariante, segundo a explicita disposição do art. 873, n. ${ }^{\circ}$ II do Codigo do Processo, que se ha de dizer de uma acção como essa, que representa a subversão completa da successão estabelecida pelo autor da herança?

Emquanto não forem annulladas as disposições testamentarias, têm de ser observadas no processo do inventario. 0 herdeiro que as impugna em acção annulatoria do testamento não póde, sem malicia, assignar o compromisso de cumprilas no processo de inventario. 